CURRENT RESEARCH JOURNAL OF PHILOLOGICAL SCIENCES 2(9): 35-39,

September 2021

DOI: https://doi.org/10.37547/philological-crjps-02-09-08

ISSN 2767-3758

(C2021 Master Journals

Crossref do

81 Google

Accepted20th September, 2021 \& Published 25 ${ }^{\text {th }}$ September, 2021

\title{
THE GREAT ENCYCLOPEDIA OF FOLK GENIUS
}

\author{
Shukhratkhon Salijanovna Imyaminova \\ Professor, National University Of Uzbekistan
}

Sodirjon Yakubov

Associate Professor, National University Of Uzbekistan

\section{ABSTRACT}

The ancient and rich literary traditions of the peoples of Central Asia have been proven by orientalists. One of them is folk oral epics, myths and legends, stories and legends. They are developed in two languages Turkish and Persian. The Turkic peoples of Central Asia, along with their oral creations, made rich use of the rich legends and epic epics of the ancestors of the Iranian peoples and continued to add their own creations. The most significant epic in which there is a commonality between them.

KEYWORDS: - Epics, “Alpomish”, Barchin, Abulqasim Firdavsi, “Shohnoma”, Rustam, Rustami Doston.

\section{INTRODUCTION}

Like other nations, our peoples have an ancient and very rich epic heritage, that is, works that cover a wide range of mythological and historical events, and analyze them artistically. They are called folk epics.

In this article, the artistic value of the epic "Alpomish". In this epic, the conflict between the brothers Boybori and Boysari divides the people of Kungrad into two. Part of it was moved to the land of the Kalmyks, led by Boysari. Heavy views, after complex events, the people of Kungrad reunite.

The epic "Alpomish" is an artistic expression of the courageous struggle of the people of Central Asia against foreign invaders.

The main idea of the epic is the struggle of the people for freedom and independence, the struggle for peace and justice, the noble aspirations of man in life.

This epic is also spread among Karakalpaks, Kazakhs, Tatars, Bashkirs and Tajiks in different variants. Their commonality testifies to the fact that the peoples of Central Asia have lived in friendship and cooperation for a long time, fighting together against foreign invaders for their hopes, freedoms and independence.

The ancient literary monument of the Turkic peoples, the Book of Dada-Korkut, was copied from 
CURRENT RESEARCH JOURNAL OF PHILOLOGICAL SCIENCES 2(9): 35-39,

September 2021

DOI: https://doi.org/10.37547/philological-crjps-02-09-08

ISSN 2767-3758

(C)2021 Master Journals

Crossref do

81 Google

Accepted20 ${ }^{\text {th }}$ September, 2021 \& Published 25 ${ }^{\text {th }}$ September, 2021

oral literature in the 16th century. In this play one can see the formation and development of folk epic creativity. This book tells the story of Boyandirkhan, the ruler of the Oguzs, and his heroic heroes. Folk history singer Korkut Bobo sang with a drum, reciting what he saw and knew. He is both a singer and a participant in the events of the book, a wise counselor of the people. Scholars consider the story of Bamsi-Bayrak in the book to be an ancient source of Alpomish.

The plates of nomadic life and patriarchal relations of the Oghuz people, the image of courage of Boyandirkhan's heroes, epic scale and stylistic features are continued and improved in Alpomish. Alpomish is a poem that glorifies courage and heroism, love and patriotism for the people, family strength and love for each other.

It appeared thousands of years ago at a time when the feudal system was beginning to take shape in the lower reaches of the Syrdarya - the Kipchak steppes, when patriarchal patriarchal relations were still incomplete.

It was created on the basis of the epic traditions of the Turkic tribes. It reflects the migration of the Dashti Kipchak tribes to different places, the occasional division and addition of bells, and the emergence of different Turkic peoples.

Scholars divide the epic "Alpomish" into two parts. In the first part, the birth of Alpomish, his childhood, growing up as a warrior, the courage of his youth, the mountain of his people's trust, his first heroism, and his march to save Barchin in Kalmykia, his struggle with Kalmyk heroes. There is talk of rescuing Barchin and marrying him, taking the immigrant bells and returning to his homeland. In the second part, the battles of his father-in-law and mother-in-law to save him from the tyranny of Toychakhan, the second march to the land of
Kalmykia, the simple, trustworthy hero Alpomish was deceived by the evil sorceress Surkhayil, captured by the Kalmyks and imprisoned for seven years; the faithful horse escapes with the help of Boychibor, kills the tyrant khan, appoints his righteous friend Kaykubod as king, and returns to his homeland.

Alpomish's struggle for his own happiness, for the happiness of his family, is inextricably linked with the happiness of the people, the unification, prosperity, peace of the homeland, the struggle against evil and deceitful rulers, the struggle against foreign invaders and oppressors.

The victory of good over evil, its courage, bravery, hatred of the wild, loyalty to a friend, sincere kindness to the people, the best hopes of the people for human freedom are reflected in the images of Alpomish, Barchinoy, Swallow, Karajon, Kaykubod. Alpomish also has many similarities with other famous epic epics, which indicates that it is in harmony with the epic heritage of the peoples of the world. For example, if we look at the epic "Shohnoma" written by Abulqasim Firdavsi, both his protagonist Rustam and Alpomish had supernatural heroism and great power since childhood, both of which grew rapidly and showed heroism as children. As they grow older, they themselves crush entire armies. Their horses, Boychibor and Rakhsh, are also not ordinary horses, only named after Alpomish and Rustam. Both are called war friends, their people balogardonim.

The level of art of the epic "Alpomish" is also very high, so it is no exaggeration to say that it is one of the works that deserves a place in the treasury of world art.

Its plot is complex but interesting, the composition is clear and well thought out, the style is unique, different genres are used in place. In it, along with 
CURRENT RESEARCH JOURNAL OF PHILOLOGICAL SCIENCES 2(9): 35-39,

September 2021

DOI: https://doi.org/10.37547/philological-crjps-02-09-08

ISSN 2767-3758

(C)2021 Master Journals

Crossref doi

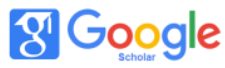

Accepted20 $0^{\text {th }}$ September, 2021 \& Published 25 $5^{\text {th }}$ September, 2021

sharp dramatic events, a wide range of epic stories and light humor or satirical revelations, lyrical retreats expressing deep human feelings make this great book interesting for the reader or listener, increasing its impact on the human mind. . There are also a lot of fantasy stories in it. But they, too, are absorbed in the texture of the work as believable, as in real-life events.

In the play, prose and poetic pieces complement each other. While the details of the event, natural landscapes, vital details, and some messages are given in the prose part, often the arguments between the protagonists, pain, home worries, and love passion, joy of victory, heroism, and battle images and so on are expressed poetically.

The heroes of this epic, carved over the centuries, cultivate in a person high ideals, a sense of nobility, honesty and courage. The second work cited in this book is Firdausi's "Shohnama", the best example of a written epic.

Abulqasim Firdavsi, a great scholar of his time, who lived and worked a thousand years ago, was able to study the richness of folklore and describe it in a huge book.

From the day of its publication, the great Firdausi's "Shohnama" gave joy to anyone who read it, became famous wherever he set foot, conquered the kingdom of any country, and conquered the whole world in the last thousand years. It is a wonderful work, which, despite its longevity, has not aged, but has become more and more youthful and youthful. In "Shohnoma" a number of mythical forces, demons, witches, giants, and fairies often become ordinary people. They are embodied in human nature as good or evil, not in appearance. The protagonists of the "Shohnama", although they have some mythical qualities, are human beings.
The "Shohnama" describes the period of fifty kingdoms. It tells the story of the history of the peoples of Iran and Central Asia, from the most ancient (legendary) periods to the Arab conquest. Scholars who examined the epic divided it into three parts.

The first is the legendary part. In it, the poet artistically develops ancient legends. The second: a heroic epic. This section mainly consists of stories about Rustami Doston, his father Zol, grandfather Som and other heroes. For example, Gudarz and his sons - Shaydush, Nastukh, Bahrom, Ruhhom, Hajir, Gev, Nevzod and others. Third: the historical section. It covers the historical art of the peoples of Iran and Central Asia from the Sassanid period to the Arab invasion.

The main idea of the epic is the idea of a struggle between the forces of good and evil. The image of the kings in the book is rather dry, schematic, resembling symbols cast only to mark periods. The real heroes of the epic are the heroes who act in it.

The main protagonist of the epic is Rustami Doston. $\mathrm{He}$ is the backbone of his native Iran, with his courage the country will be saved from many troubles, survive the attack of the invaders, the people will be freed from the clutches of foreigners. Rustami Doston is a real national hero. Until the last day, people will love him and name him after his children.

Firdavsi's "Shohnoma" is a very popular work. It describes true patriotism, heroism, creative and positive human activity.

Another epic that has touched the hearts of many for centuries in the Shahnameh is the epic Rustam and Sukhrob, translated into Russian by the poet Zhukovsky. Always striving for western glory, Rustam, full of pride in victory, stabbed his son Sukhrob in the chest without recognizing him in 
CURRENT RESEARCH JOURNAL OF PHILOLOGICAL SCIENCES 2(9): 35-39,

September 2021

DOI: https://doi.org/10.37547/philological-crjps-02-09-08

ISSN 2767-3758

(C2021 Master Journals

Crossref do

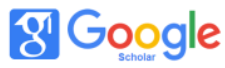

Accepted20 ${ }^{\text {th }}$ September, 2021 \& Published 25 ${ }^{\text {th }}$ September, 2021

battle. Suhrob will perish. The plight of the great warrior, who carried his son's lifeless body and wept, his anguish, Sukhrob's mother's moan, the painful fig on the coffin of his grandfather Som's grandson, aroused anti-war hatred in the reader.

The realism of the great Ferdowsi goes beyond the boundaries of his worldview, which is related to his own time, the truth of which does not fit into the scope of his narrow class views.

In this respect, the story of the Mazdak in particular is characteristic. Mazdak is a historical figure who lived in the late 5th and early 6th centuries. He is the leader of a very large popular uprising. According to Mazda, private property is the mother of all evils in human society. According to his teachings, two forces in the world are in constant struggle. One is ignorance and ignorance, which is the source of darkness, and the other, is the source of light - knowledge.

Mazdak calls for the elimination of the dark forces from the world. The ruling class, which eats without work, also adds to the dark forces. Mazdak supporters' revolts spread throughout Iran. They confiscate the land and property of the feudal lords and distribute it to the dehkans. Kubod horn helps the rebels. Because he wants to take revenge on some khans who are not subordinate to the central state.

At a time when ancient historians have described the Mazdak movement as a revolt of a group of accusers, Firdausi sings this national hero with perfect love. This is another great feature that instills the epic in the hearts of the people.

The great Russian revolutionary-democratic writer N. G. Chernyshevsky praised the populism of the "Shohnoma" and praised it:

... Firdavsi's wonderful work is a collection of folk songs "Shohnoma" and their rework. There are so many beautiful things in it that you can't find them in the "Iliad" or the "Odessa".

In these words, some of the masterpieces in the "Shohnoma" are valued even higher than the works of the ancient Greek poet Homer in the Odyssey and Iliad, but it also explains where the secret of such success lies. The secret of this lies in the fact that the "Shohnoma" is based on folk art, its true meaning is populism.

The image of righteous kings, the image of heroes who are always ready to defend the homeland, the image of true friends, devoted women, and many other qualities have made this book a real people's property.

Ferdowsi's language also adopts a style that has been developed by the genius of the people for many centuries, raising it to new artistic heights. That is why many bytes of the epic have been added to folk proverbs. It is difficult to distinguish which of them was a proverb first, then entered the "Shohnoma", and which became a proverb after Firdausi.

\section{ReFERENCES}

1. Imyaminova, S. S., \& Yakubov, S. B. (2021). To the question about the history of uzbekgerman cultural relations (1960-1975). Asian Journal of Multidimensional Research (AJMR), 10(1), 84-88.

2. Ismatullayeva, N. R. (2019). Lacunas in Chinese and Uzbek languages and methods of their detection. International Journal of Innovative Technology and Exploring Engineering, 8(12), 2095-2099.

3. Rasuljanovna, I. N. (2019). Lacunas Occurance In Semantic Fields of Chinese And Uzbek Languages. International Journal of Scientific \& Technology Research, 8(11), 1998-2001.

4. Saidakbarova, S. P. (2020). Fruit And Vegetables... Exploring Gastronomic Idioms In 
CURRENT RESEARCH JOURNAL OF PHILOLOGICAL SCIENCES 2(9): 35-39,

September 2021

DOI: https://doi.org/10.37547/philological-crjps-02-09-08

ISSN 2767-3758

(C)2021 Master Journals

Crossref doi 81 Google

Accepted20 $0^{\text {th }}$ September, 2021 \& Published 25 $5^{\text {th }}$ September, 2021

English And Uzbek (The Linguo-Cultural Analysis Of English And Uzbek Phraseological Units With The Components Fruit And Vegetables). CURRENT RESEARCH JOURNAL OF PHILOLOGICAL SCIENCES (2767-3758), 1(01), 24-32.

5. Usmanova, S. (2008). Notes on Some Altaic Household Words. Manas Üniversitesi Sosyal Bilimler Dergisi, 19, 123-128.

6. Usmanova, S. (2020). The Specialties of Uzbek Collectivism Culture. Journal of Multiculture and Education, 5(1), 71-86.

7. Usmanova, S. ALTAY DİLLERINDE ÜST GIYSİ ADLARI. Türk Dünyası İncelemeleri Dergisi, 11(1), 15-23.

8. Usmanova, S. R. (2021). The Application Of The Method Of Metamorphosis In The Folklore of The Peoples of The East. Psychology and Education Journal, 58(1), 1033-1042.

9. Usmanova, S. R., \& Ismatullayeva, N. R. (2020). Expression Of Lacunas In Comparative Study Of Kinship Terms In Chinese And Uzbek Languages. Solid State Technology, 63(6), 4974-4985.

10. Yakubov, S. B. (2020). OCTOBER 21, DAY OF THE STATE LANGUAGE-UZBEK LANGUAGE. CONNECTING NATION MEDIUM. Journal of Central Asian Social Studies, 1(02), 1-6.

11. Yakubov, S. B. (2020). ON EDUCATING PRACTICE OF CULTURAL-LITERARY INTERRELATIONS (ON THE MATERIALS OF CULTURAL AND LITERARY RELATIONS BETWEEN UZBEKISTAN AND GERMANY). Solid State Technology, 314-322.

12. Yakubov, S. B. (2021). Cultural Relationship of Uzbekistan and Germany (In Historical Aspect). International Journal of Multicultural and Multireligious Understanding, 8(4), 156159.

13. Yakubov, S. B. (2021). TRANSLATIONS OF WORKS BY GERMAN WRITERS INTO UZBEK (BASED ON TRANSLATIONS OF GOETHE'S
"FAUST" AND “THE DEAD REMAIN YOUNG” BY ANNA ZEGERS). Frontline Social Sciences and History Journal, 14-21.

14. Имяминова, Ш., \& Якубов, С. (2021). УЗБЕКСКАЯ ЛИТЕРАТУРА НА НЕМЕЦКОМ ЯЗЫКЕ НА ПРИМЕРАХ УЗБЕКСКИХ ПИСАТЕЛЕЙ АБДУЛЛА КАДИРИ И АБДУЛЛА КАХХАРA. In Фундаментальные и прикладные научные исследования: актуальные вопросы, достижения и инновации (рp. 102-104). 